\title{
Convenient Synthesis of 1,4-Dideoxy-1,4-imino-D-ribitol from D-Ribose
}

\author{
Makoto Oba, Shoi Kawaji, Hironobu Kushima, Takanori Sano, and Kozaburo Nishiyama \\ Department of Materials Chemistry, Tokai University, 317 Nishino, Numazu, Shizuoka 410-0395, Japan \\ Correspondence should be addressed to Makoto Oba; moba@tokai-u.jp
}

Received 30 April 2013; Accepted 5 June 2013

Academic Editor: Zurina Shaameri

Copyright (C) 2013 Makoto Oba et al. This is an open access article distributed under the Creative Commons Attribution License, which permits unrestricted use, distribution, and reproduction in any medium, provided the original work is properly cited.

This paper describes a convenient synthesis of 1,4-dideoxy-1,4-imino-D-ribitol (DRB) from D-ribose. L-Lyxonolactone, a key intermediate in this synthesis, was prepared by base-promoted hydrolysis of a 5-chlorinated D-ribonolactone derivative with inversion of configuration at the C-4 position. Cyclization of the generated dimesylated L-lyxitol with benzylamine proceeded with another configurational inversion at C-4 to afford the D-ribo-configured pyrrolidine system, which upon deprotection gave DRB.

\section{Introduction}

1,4-Dideoxy-1,4-imino-D-ribitol (DRB, 1) is a polyhydroxylated pyrrolidine alkaloid isolated from the roots of mulberry trees (Morus alba) [1] and from the bark and pods of leguminous plants (Angylocalyx pynaertii) [2, 3]. Owing to its structural [4-aza]ribofuranose feature, DRB and its derivatives have attracted considerable attention as enzyme inhibitors that mimic glycoside and nucleoside substrates. In fact, DRB was found to be a potent inhibitor of lysosomal $\beta$-mannosidase [3] and eukaryotic DNA polymerases [4] and was also employed as a synthetic precursor of some enzyme inhibitors containing the [4-aza] ribosyl group [5-8]. Therefore, there is a need to develop a simple method for the preparation of DRB derivatives.

Two major approaches have been used to construct the DRB framework. One is the stereoselective dihydroxylation of optically active 2-substituted 3-pyrroline derivatives, in which the oxidation is usually carried out using a highly toxic osmium catalyst [9-13]; the other is a sugar-based approach. The D- and L-forms of 1,4-dideoxy-1,4-iminoribitol were prepared from D-gulonolactone (29\% overall yield over 9 steps) and D-mannose (28\% overall yield over 9 steps), respectively [14-16]. From the viewpoint of atom economy, pentose as a starting material is more favorable. Recently, a related study was reported by Mercer and coworkers [17], in which both enantiomers of 1,4-dideoxy-1,4-iminolyxitol were efficiently synthesized from D- and L-ribonolactone. Since the process involves configurational inversion at the C-4 position, a straightforward precursor to $\mathrm{DRB}$ is considered to be L-lyxose, which is an expensive unnatural pentose. Herein, we describe a convenient synthesis of DRB starting from Dribose via L-lyxonolactone, in which the D-ribo-configured pyrrolidine ring is constructed with overall retention of the stereochemistry at C-4 by a double inversion.

\section{Results and Discussion}

The synthetic route to DRB is illustrated in Scheme 1. 2,3$O$-Isopropylidene-D-ribono-1,4-lactone (2) is easily obtained from inexpensive D-ribose using a well-established procedure $[18,19]$ or is commercially available. At the beginning of the synthesis, we examined the conversion of D-ribonolactone 2 to L-lyxonolactone 4 with inversion of stereochemistry at C-4. A production-scale synthesis of 4 from 2 via a 5$O$-methanesulfonyl derivative was reported (59\% yield at a $200 \mathrm{~kg}$ scale) [18]; however, we experienced variable yields at a laboratory scale. In this study, therefore, we adopted an alternative route via the corresponding chloride 3 .

Chlorination of the hydroxyl group at C-5 of 2 was performed using a Vilsmeier reagent prepared in situ from DMF 

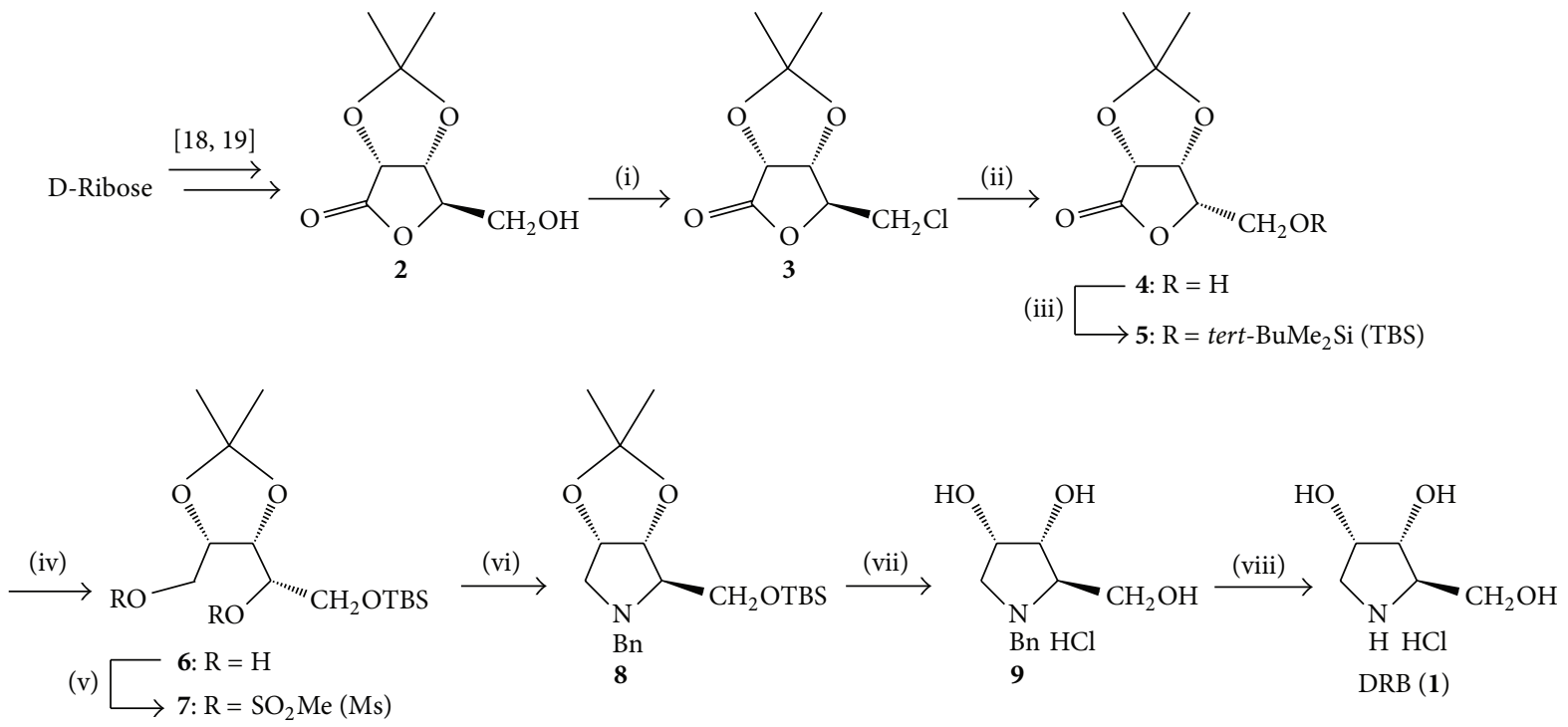

Scheme 1: Synthesis of DRB (1). Reagents and conditions: (i) (COCl) ${ }_{2}, \mathrm{DMF}, \mathrm{CH}_{2} \mathrm{Cl}_{2}, 97 \%$; (ii) $\mathrm{KOH}, \mathrm{H}_{2} \mathrm{O}$, then, $3 \mathrm{M} \mathrm{HCl}$, quant; (iii) TBSCl, imidazole, $\mathrm{CH}_{2} \mathrm{Cl}_{2}, 91 \%$; (iv) $\mathrm{NaBH}_{4}, \mathrm{MeOH}, 95 \%$; (v) $\mathrm{MsCl}$, pyridine, $85 \%$; (vi) $\mathrm{PhCH}_{2} \mathrm{NH}_{2}\left(\mathrm{BnNH}_{2}\right.$ ), toluene, $86 \%$; (vii) $1 \mathrm{M} \mathrm{HCl}$, quant; and (viii) $\mathrm{H}_{2}, 10 \% \mathrm{Pd} / \mathrm{C}, \mathrm{H}_{2} \mathrm{O}$, quant.

and oxalyl chloride to afford 5-chloro-5-deoxy derivative 3 in $97 \%$ yield [20]. Treatment of chloride 3 with an aqueous $\mathrm{KOH}$ solution followed by acidification gave 2,3$O$-isopropylidene-L-lyxono-1,4-lactone (4) in quantitative yield. It is believed that configurational inversion at the C-4 position occurred as reported for the mesylate reaction [21]. Namely, a base-promoted ring opening of the chlorinated ribonolactone 3 followed by intramolecular $S_{\mathrm{N}} 2$ reaction gave epoxide 10 (Scheme 2). Subsequent 5-exo-tet [22] ring closure between the carboxylate and epoxide proceeded with inversion of configuration at C- 4 to furnish the lactone, which was then hydrolyzed to the open-chain derivative $\mathbf{1 1}$ under strongly basic conditions. Upon acidification, carboxylate $\mathbf{1 1}$ immediately cyclized to lyxonolactone 4 .

After protection of the primary hydroxyl group of $\mathbf{4}$ as a tert-butyldimethylsilyl (TBS) ether in $91 \%$ yield, the fully protected lactone $\mathbf{5}$ was subjected to reductive ring opening by $\mathrm{NaBH}_{4}$ in $\mathrm{MeOH}$ to afford partially protected L-lyxitol derivative $\mathbf{6}$ in 95\% yield. Diol $\mathbf{6}$ was then treated with methanesulfonyl chloride in pyridine to give the corresponding dimesylate 7 in $85 \%$ yield. Cyclization of 7 with benzylamine involving inversion at C-4 was performed in refluxing toluene for 3 days to give fully protected DRB 8 in $86 \%$ yield. Acidic hydrolysis of both the acetonide and TBS protective groups in $1 \mathrm{M} \mathrm{HCl}$ gave $N$-benzyl DRB derivative 9 in quantitative yield. Finally, DRB was quantitatively obtained as its hydrochloride salt by catalytic hydrogenolysis of the $N$-benzyl group. Comparison of the physical and spectral data of DRB with the literature data completely confirmed its identity.

In conclusion, we have achieved a convenient synthesis of DRB in $61 \%$ overall yield from D-ribonolactone 2 over eight steps. The D-ribo-configured pyrrolidine system was constructed with overall retention of the stereochemistry at C- 4 by a double $S_{\mathrm{N}} 2$ inversion.

\section{Experimental}

3.1. General. Melting points were determined using a Yamato MP-21 melting point apparatus in open capillaries and are uncorrected. ${ }^{1} \mathrm{H}$ and ${ }^{13} \mathrm{C}$-nuclear magnetic resonance (NMR) spectra were measured on a Varian Mercury plus 400 spectrometer at 400 and $100 \mathrm{MHz}$, respectively. All chemical shifts are reported as $\delta$ values (ppm) relative to residual chloroform $\left(\delta_{\mathrm{H}} 7.26\right)$, HDO $\left(\delta_{\mathrm{H}} 4.79\right)$, the central peak of deuteriochloroform $\left(\delta_{\mathrm{C}} 77.0\right)$, or dioxane $\left(\delta_{\mathrm{C}} 67.2\right)$; $J$ values are expressed in $\mathrm{Hz}$. Optical rotations were measured on a HORIBA SEPA-200 polarimeter. Elemental analyses were performed using a PerkinElmer 2400 Series II analyzer.

All reagents and solvents were of commercial grade and used according to supplier instructions unless otherwise mentioned.

3.2. 5-Chloro-5-deoxy-2,3-O-isopropylidene-D-ribono-1,4-lactone (3) $[20,23]$. DMF was added $(117 \mu \mathrm{L}, 110 \mathrm{mg}, 1.51 \mathrm{mmol})$ to a solution of oxalyl chloride $(129 \mu \mathrm{L}, 194 \mathrm{mg}, 1.52 \mathrm{mmol})$ in $\mathrm{CH}_{2} \mathrm{Cl}_{2}(4 \mathrm{~mL})$ at $0^{\circ} \mathrm{C}$, and the mixture was stirred for $12 \mathrm{~min}$. To the resultant cloudy suspension, a solution of compound 2 (188 mg, $0.999 \mathrm{mmol})$ in $\mathrm{CH}_{2} \mathrm{Cl}_{2}(2 \mathrm{~mL})$ was added dropwise at the same temperature, and the mixture was refluxed for $90 \mathrm{~min}$. The cooled reaction mixture was diluted with $\mathrm{CHCl}_{3}$, washed with brine, and dried over $\mathrm{MgSO}_{4}$. After removal of the solvent, the residue was chromatographed on $\mathrm{SiO}_{2}$. Elution with a mixture of hexane and AcOEt (7/3) gave compound 3 (200 mg, $0.968 \mathrm{mmol}, 97 \%$ ) as a white solid. An analytical sample was obtained by recrystallization from a mixture of EtOH and acetone. Colorless powder, $\mathrm{mp}$ 97.5-98.5 ${ }^{\circ}$ C. $[\alpha]_{\mathrm{D}}{ }^{23}-60.8\left(c 1.00, \mathrm{CHCl}_{3}\right) .{ }^{1} \mathrm{H}-\mathrm{NMR}\left(\mathrm{CDCl}_{3}\right)$ $\delta 1.40(\mathrm{~s}, 3 \mathrm{H}), 1.49(\mathrm{~s}, 3 \mathrm{H}), 3.79(\mathrm{dd}, J=12$ and $2 \mathrm{~Hz}, 1 \mathrm{H}), 3.85$ $(\mathrm{dd}, J=12$ and $3 \mathrm{~Hz}, 1 \mathrm{H}), 4.74(\mathrm{~d}, J=6 \mathrm{~Hz}, 1 \mathrm{H}), 4.87(\mathrm{dd}, J=3$ 

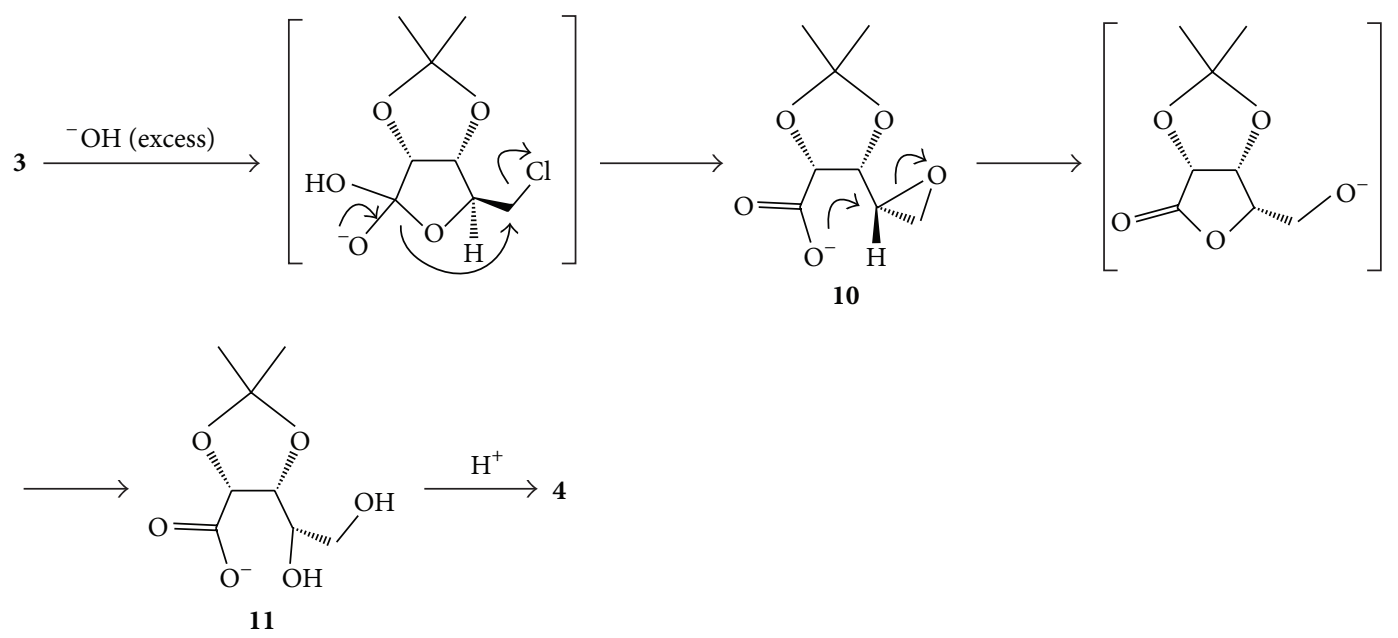

Scheme 2: Plausible reaction pathway for the configurational inversion at C-4 by base-promoted hydrolysis of lactone 3.

and $2 \mathrm{~Hz}, 1 \mathrm{H}), 4.89(\mathrm{~d}, J=6 \mathrm{~Hz}, 1 \mathrm{H}) .{ }^{13} \mathrm{C}-\mathrm{NMR}\left(\mathrm{CDCl}_{3}\right) \delta$ 25.4, 26.5, 44.7, 75.2, 78.2, 80.8, 113.7, 173.3.

3.3. 2,3-O-Isopropylidene-L-lyxono-1,4-lactone (4) [18]. Compound 3 (207 mg, $1.00 \mathrm{mmol}$ ) was added to a $2.5 \mathrm{M}$ aqueous solution of $\mathrm{KOH}(1.00 \mathrm{~mL}, 2.50 \mathrm{mmol})$, and the resulting mixture was stirred at room temperature overnight. The solution was acidified with $3 \mathrm{M} \mathrm{HCl}$ to $\mathrm{pH} 3$ and concentrated. The residue was triturated with acetone $(6 \mathrm{~mL})$ and heated to reflux. After removal of the insoluble materials by filtration, the filtrate was dried over $\mathrm{MgSO}_{4}$ and concentrated under reduced pressure to give compound $\mathbf{4}$ $(193 \mathrm{mg})$ in quantitative yield as a white solid, $\mathrm{mp} 94-95^{\circ} \mathrm{C}$ (lit [18], mp 98-99 $\mathrm{C}) .[\alpha]_{\mathrm{D}}{ }^{25}-88.0$ (c 0.50 , acetone) (lit [18], $[\alpha]_{\mathrm{D}}{ }^{25}-89.0(c 1.00$, acetone $\left.)\right) .{ }^{1} \mathrm{H}-\mathrm{NMR}\left(\mathrm{CDCl}_{3}\right) \delta 1.40(\mathrm{~s}$, $3 \mathrm{H}), 1.49(\mathrm{~s}, 3 \mathrm{H}), 2.10(\mathrm{br} \mathrm{s}, 1 \mathrm{H}), 3.97(\mathrm{dd}, J=12$ and $5 \mathrm{~Hz}$, $1 \mathrm{H}), 4.04(\mathrm{dd}, J=12$ and $7 \mathrm{~Hz}, 1 \mathrm{H}), 4.60$ (ddd, $J=7,5$, and $4 \mathrm{~Hz}, 1 \mathrm{H}), 4.87(\mathrm{~d}, J=6 \mathrm{~Hz}, 1 \mathrm{H}), 4.89(\mathrm{dd}, J=6$ and $4 \mathrm{~Hz}$, 1H). ${ }^{13} \mathrm{C}-\mathrm{NMR}\left(\mathrm{CDCl}_{3}\right) \delta 25.7,26.6,60.8,76.1,76.2,79.1$, 114.5, 173.5 .

3.4. 5-O-tert-butyldimethylsilyl-2,3-O-isopropylidene-L-lyxono-1,4-lactone (5) [24]. A solution of compound $4(193 \mathrm{mg})$, tert- $\mathrm{BuMe}{ }_{2} \mathrm{SiCl}$ (166 mg, $1.10 \mathrm{mmol}$ ), and imidazole (102 mg, $1.50 \mathrm{mmol})$ in $\mathrm{CH}_{2} \mathrm{Cl}_{2}(3 \mathrm{~mL})$ was stirred at room temperature for $1 \mathrm{~h}$. The reaction mixture was then diluted with $\mathrm{CHCl}_{3}$, washed with brine, and dried over $\mathrm{MgSO}_{4}$. After removal of the solvent, the residue was chromatographed on $\mathrm{SiO}_{2}$. Elution with a mixture of hexane and AcOEt (7/3) gave compound 5 ( $276 \mathrm{mg}, 0.913 \mathrm{mmol}, 91 \%)$ as a white solid. An analytical sample was obtained by recrystallization from hexane. Colorless powder, $\mathrm{mp} 87-88^{\circ} \mathrm{C}$ (data for enantiomer [25]: $\left.\mathrm{mp} 90-91^{\circ} \mathrm{C}\right) \cdot[\alpha]_{\mathrm{D}}{ }^{27}-52.2\left(c 1.00, \mathrm{CHCl}_{3}\right.$ ) (data for enantiomer [25]: $\left.[\alpha]_{\mathrm{D}}{ }^{22}+54.9\left(c 1.03, \mathrm{CHCl}_{3}\right)\right) .{ }^{1} \mathrm{H}-\mathrm{NMR}$ $\left(\mathrm{CDCl}_{3}\right) \delta 0.09(\mathrm{~s}, 6 \mathrm{H}), 0.90(\mathrm{~s}, 9 \mathrm{H}), 1.38(\mathrm{~s}, 3 \mathrm{H}), 1.45(\mathrm{~s}$, $3 \mathrm{H}), 3.93(\mathrm{dd}, J=11$ and $7 \mathrm{~Hz}, 1 \mathrm{H}), 3.97(\mathrm{dd}, J=11$ and $6 \mathrm{~Hz}$, $1 \mathrm{H}), 4.52(\mathrm{ddd}, J=7$ and 6 and $2 \mathrm{~Hz}, 1 \mathrm{H}), 4.79-4.82(\mathrm{~m}, 2 \mathrm{H})$. ${ }^{13} \mathrm{C}-\mathrm{NMR}\left(\mathrm{CDCl}_{3}\right) \delta-5.6,-5.4,18.3,25.7,25.8,26.7,60.8$, 75.7, 76.0, 79.4, 114.0, 173.8.
3.5. 5-O-tert-butyldimethylsilyl-2,3-O-isopropylidene-L-lyxitol (6) [24]. $\mathrm{NaBH}_{4}$ (351 mg, $9.28 \mathrm{mmol}$ ) was added to a solution of compound 5 (561 mg, $1.85 \mathrm{mmol})$ in $\mathrm{MeOH}$ $(19 \mathrm{~mL})$ at $0^{\circ} \mathrm{C}$, and the resulting mixture was stirred at room temperature for $1 \mathrm{~h}$. After removal of the solvent, the residue was diluted with $\mathrm{CHCl}_{3}$, washed with saturated aqueous $\mathrm{NaHCO}_{3}$, dried over $\mathrm{MgSO}_{4}$, and concentrated under reduced pressure to give compound $6(543 \mathrm{mg}, 1.77 \mathrm{mmol}$, $96 \%$ ) as a white solid. An analytical sample was obtained by recrystallization from hexane. Colorless powder, $\mathrm{mp} 64-65^{\circ} \mathrm{C}$ (data for enantiomer [25]: $\left.\mathrm{mp} 67-68^{\circ} \mathrm{C}\right) \cdot[\alpha]_{\mathrm{D}}{ }^{26}+9.3(c 1.02$, $\mathrm{CHCl}_{3}$ ) (data for enantiomer [25]: $[\alpha]_{\mathrm{D}}{ }^{23}-9.2$ (c 0.08 , $\left.\left.\mathrm{CHCl}_{3}\right)\right) .{ }^{1} \mathrm{H}-\mathrm{NMR}\left(\mathrm{CDCl}_{3}\right) \delta 0.08(\mathrm{~s}, 6 \mathrm{H}), 0.90(\mathrm{~s}, 9 \mathrm{H}), 1.38$ $(\mathrm{s}, 3 \mathrm{H}), 1.51(\mathrm{~s}, 3 \mathrm{H}), 2.83(\mathrm{dd}, J=7$ and $5 \mathrm{~Hz}, 1 \mathrm{H}), 2.90(\mathrm{~d}, J=$ $5 \mathrm{~Hz}, 1 \mathrm{H}), 3.63(\mathrm{dd}, J=10$ and $7 \mathrm{~Hz}, 1 \mathrm{H}), 3.72(\mathrm{dd}, J=10$ and $6 \mathrm{~Hz}, 1 \mathrm{H}), 3.77-3.85(\mathrm{~m}, 3 \mathrm{H}), 4.23-4.25(\mathrm{~m}, 2 \mathrm{H}) .{ }^{13} \mathrm{C}-\mathrm{NMR}$ (CDCl3) $\delta-5.5,-5.4,18.2,25.0,25.8,27.1,61.3,64.5,69.1$, $75.7,77.3,108.2$.

3.6. 5-O-tert-butyldimethylsilyl-1,4-di-O-methanesulfonyl2,3-O-isopropylidene-L-lyxitol (7) [24]. Methanesulfonyl chloride $(0.411 \mathrm{~mL}, 608 \mathrm{mg}, 5.31 \mathrm{mmol})$ was added to a solution of compound $6(543 \mathrm{mg}, 1.77 \mathrm{mmol})$ in pyridine $(10 \mathrm{~mL})$ at $0^{\circ} \mathrm{C}$, and the resulting mixture was stirred at room temperature overnight. After removal of the solvent, the residue was diluted with AcOEt, successively washed with $1 \mathrm{M} \mathrm{HCl}$ and saturated aqueous $\mathrm{NaHCO}_{3}$, dried over $\mathrm{MgSO}_{4}$, and concentrated under reduced pressure to give compound $7(695 \mathrm{mg}, 1.50 \mathrm{mmol}, 85 \%)$ as a colorless oil. $[\alpha]_{\mathrm{D}}{ }^{26}-5.5(c$ $1.02, \mathrm{CHCl}_{3}$ ) (data for enantiomer [25]: $[\alpha]_{\mathrm{D}}{ }^{24}+5.0(c 0.14$, $\left.\left.\mathrm{CHCl}_{3}\right)\right) .{ }^{1} \mathrm{H}-\mathrm{NMR}\left(\mathrm{CDCl}_{3}\right) \delta 0.097(\mathrm{~s}, 3 \mathrm{H}), 0.103(\mathrm{~s}, 3 \mathrm{H})$, $0.90(\mathrm{~s}, 9 \mathrm{H}), 1.38(\mathrm{~s}, 3 \mathrm{H}), 1.51(\mathrm{~s}, 3 \mathrm{H}), 3.08(\mathrm{~s}, 3 \mathrm{H}), 3.11(\mathrm{~s}, 3 \mathrm{H})$, $3.83(\mathrm{dd}, J=11$ and $6 \mathrm{~Hz}, 1 \mathrm{H}), 3.96(\mathrm{dd}, J=11$ and $5 \mathrm{~Hz}, 1 \mathrm{H})$, $4.37-4.45(\mathrm{~m}, 4 \mathrm{H}), 4.74(\mathrm{~m}, 1 \mathrm{H}) .{ }^{13} \mathrm{C}-\mathrm{NMR}\left(\mathrm{CDCl}_{3}\right) \delta-5.6$ (2C overlapped), 18.2, 25.4, 25.8, 27.2, 37.6, 38.9, 63.1, 67.9, 74.4, 75.3, 78.9, 109.6 .

3.7. N-Benzyl-5-O-tert-butyldimethylsilyl-2,3-O-isopropylidene-1,4-dideoxy-1,4-imino-D-ribitol hydrochloride (8) $[5,8]$. 
A mixture of compound 7 (695 mg, $1.50 \mathrm{~mol})$ and benzylamine $(891 \mu \mathrm{L}, 874 \mathrm{mg}, 8.16 \mathrm{mmol})$ in toluene $(8 \mathrm{~mL})$ was heated to reflux for 3 days. The reaction mixture was then diluted with $\mathrm{CHCl}_{3}$, successively washed with water and saturated aqueous $\mathrm{NaHCO}_{3}$, and dried over $\mathrm{MgSO}_{4}$. After removal of the solvent, the residue was chromatographed on $\mathrm{SiO}_{2}$. Elution with a mixture of hexane and AcOEt (9/1) gave compound $8(487 \mathrm{mg}, 1.29 \mathrm{mmol}, 86 \%)$ as a colorless oil. $[\alpha]_{\mathrm{D}}{ }^{27}-28.0\left(c 1.01, \mathrm{CHCl}_{3}\right) .{ }^{1} \mathrm{H}-\mathrm{NMR}\left(\mathrm{CDCl}_{3}\right) \delta 0.07(\mathrm{~s}$, $3 \mathrm{H}), 0.09(\mathrm{~s}, 3 \mathrm{H}), 0.92(\mathrm{~s}, 9 \mathrm{H}), 1.35(\mathrm{~s}, 3 \mathrm{H}), 1.58(\mathrm{~s}, 3 \mathrm{H}), 2.74$ (dd, $J=10$ and $3 \mathrm{~Hz}, 1 \mathrm{H}), 3.03$ (ddd, $J=4,4$, and $2 \mathrm{~Hz}, 1 \mathrm{H}$ ), $3.12(\mathrm{dd}, J=10$ and $6 \mathrm{~Hz}, 1 \mathrm{H}), 3.66(\mathrm{dd}, J=11$ and $4 \mathrm{~Hz}, 1 \mathrm{H})$, $3.74(\mathrm{~d}, J=13 \mathrm{~Hz}, 1 \mathrm{H}), 3.79(\mathrm{dd}, J=11$ and $4 \mathrm{~Hz}, 1 \mathrm{H}), 4.04$ $(\mathrm{d}, J=13 \mathrm{~Hz}, 1 \mathrm{H}), 4.58(\mathrm{dd}, J=7$ and $2 \mathrm{~Hz}, 1 \mathrm{H}), 4.67(\mathrm{ddd}, J$ $=7,6$, and $3 \mathrm{~Hz}, 1 \mathrm{H}), 7.15-7.38(\mathrm{~m}, 5 \mathrm{H}) .{ }^{13} \mathrm{C}-\mathrm{NMR}\left(\mathrm{CDCl}_{3}\right)$ $\delta-5.6,-5.5,18.2,25.1,25.9,27.1,56.9,59.2,63.1,68.8,79.4$, $83.2,111.8,126.8,128.2,128.5,139.2$.

3.8. N-Benzyl-1,4-dideoxy-1,4-imino-D-ribitol hydrochloride (9). A mixture of compound 8 (354 mg, $0.938 \mathrm{mmol})$ and $1 \mathrm{M} \mathrm{HCl}(10 \mathrm{~mL})$ was refluxed for $1 \mathrm{~h}$. The cooled solution was washed with $\mathrm{CHCl}_{3}$ and concentrated to give a quantitative yield of compound $9(250 \mathrm{mg})$ as a brown solid. An analytical sample was obtained by recrystallization from a mixture of $\mathrm{EtOH}$ and acetone. Colorless powder, mp 190-191 ${ }^{\circ} \mathrm{C}$. $[\alpha]_{\mathrm{D}}{ }^{23}+16.9\left(c 1.00, \mathrm{H}_{2} \mathrm{O}\right) .{ }^{1} \mathrm{H}-\mathrm{NMR}\left(\mathrm{D}_{2} \mathrm{O}\right) \delta 3.43(\mathrm{dd}, J=$ 13 and $3 \mathrm{~Hz}, 1 \mathrm{H}), 3.56(\mathrm{dd}, J=13$ and $4 \mathrm{~Hz}, 1 \mathrm{H}), 3.62(\mathrm{dd}, J$ $=13$ and $4 \mathrm{~Hz}, 1 \mathrm{H}), 3.68(\mathrm{ddd}, J=8,4$, and $3 \mathrm{~Hz}, 1 \mathrm{H}), 3.75$ (dd, $J=13$ and $4 \mathrm{~Hz}, 1 \mathrm{H}$ ), 4.21 (dd, $J=8$ and $4 \mathrm{~Hz}, 1 \mathrm{H}$ ), 4.37 (ddd, $J=4,4$, and $4 \mathrm{~Hz}, 1 \mathrm{H}), 4.48(\mathrm{~d}, J=13 \mathrm{~Hz}, 1 \mathrm{H}), 4.62(\mathrm{~d}, J$ $=13 \mathrm{~Hz}, 1 \mathrm{H}), 7.50-7.57(\mathrm{~m}, 5 \mathrm{H}) .{ }^{13} \mathrm{C}-\mathrm{NMR}\left(\mathrm{D}_{2} \mathrm{O}\right) \delta 57.6,57.7$, 62.0, 69.3, 70.7, 71.5, 130.0, 131.0, 131.5 (2C overlapped). Anal. Calcd for $\mathrm{C}_{12} \mathrm{H}_{18} \mathrm{NO}_{3} \mathrm{Cl}$ : C, 55.49; $\mathrm{H}, 6.99 ; \mathrm{N}, 5.39$. Found: C, 55.59; H, 7.22; N, 5.33.

3.9. 1,4-Dideoxy-1,4-imino-D-ribitol hydrochloride (DRB, 1) [14]. A mixture of compound $9(250 \mathrm{mg})$ and $10 \% \mathrm{Pd} / \mathrm{C}$ (63 mg) in $\mathrm{H}_{2} \mathrm{O}(20 \mathrm{~mL})$ was stirred at room temperature overnight under an atmospheric pressure of hydrogen. After removal of the catalyst with the use of Hyflo Super-Cel, the mixture was washed with $\mathrm{CHCl}_{3}$ and concentrated to give a quantitative yield of the compound $\mathbf{1}(162 \mathrm{mg})$ as a brown solid. An analytical sample was obtained by recrystallization from a mixture of $\mathrm{EtOH}$ and acetone. Colorless powder, $\mathrm{mp}$ $124-126^{\circ} \mathrm{C}\left(\right.$ lit $\left.[14], \mathrm{mp} 128-132^{\circ} \mathrm{C}\right) \cdot[\alpha]_{\mathrm{D}}{ }^{25}+57.7\left(c 0.14, \mathrm{H}_{2} \mathrm{O}\right)$ (lit [14], $\left.[\alpha]_{\mathrm{D}}{ }^{25}+57.6\left(c 0.59, \mathrm{H}_{2} \mathrm{O}\right)\right) .{ }^{1} \mathrm{H}-\mathrm{NMR}\left(\mathrm{D}_{2} \mathrm{O}\right) \delta 3.37$ (dd, $J=13$ and $2 \mathrm{~Hz}, 1 \mathrm{H}), 3.49$ (dd, $J=13$ and $4 \mathrm{~Hz}, 2 \mathrm{H}$ ), 3.63 (ddd, $J=9,6$, and $3 \mathrm{~Hz}, 1 \mathrm{H}$ ), $3.83(\mathrm{dd}, J=13$ and $6 \mathrm{~Hz}, 1 \mathrm{H}$ ), $3.97(\mathrm{dd}, J=13$ and $3 \mathrm{~Hz}, 1 \mathrm{H}), 4.21(\mathrm{dd}, J=9$ and $4 \mathrm{~Hz}, 1 \mathrm{H})$, 4.38 (ddd, $J=4,4$, and $2 \mathrm{~Hz}, 1 \mathrm{H}) .{ }^{13} \mathrm{C}$-NMR $\left(\mathrm{D}_{2} \mathrm{O}\right) \delta 50.2$, $58.6,62.4,70.0,71.8$.

\section{Acknowledgments}

The authors are grateful to Tokai University for support of their research activities. They would like to thank Enago (www.enago.jp) for the English language review.

\section{References}

[1] N. Asano, K. Oseki, E. Tomioka, H. Kizu, and K. Matsui, " $N$-containing sugars from Morus alba and their glycosidase inhibitory activities," Carbohydrate Research, vol. 259, no. 2, pp. 243-255, 1994.

[2] N. Asano, K. Yasuda, H. Kizu et al., "Novel $\alpha$-L-fucosidase inhibitors from the bark of Angylocalyx pynaertii (Leguminosae)," European Journal of Biochemistry, vol. 268, no. 1, pp. 35-41, 2001.

[3] K. Yasuda, H. Kizu, T. Yamashita et al., "New sugar-mimic alkaloids from the pods of Angylocalyx pynaertii," Journal of Natural Products, vol. 65, no. 2, pp. 198-202, 2002.

[4] Y. Mizushina, X. Xu, N. Asano et al., "The inhibitory action of pyrrolidine alkaloid, 1,4-dideoxy-1,4-imino-D-ribitol, on eukaryotic DNA polymerases," Biochemical and Biophysical Research Communications, vol. 304, no. 1, pp. 78-85, 2003.

[5] V. L. A. Malladi, A. J. Sobczak, T. M. Meyer, D. Pei, and S. F. Wnuk, "Inhibition of LuxS by $S$-ribosylhomocysteine analogues containing a [4-aza]ribose ring," Bioorganic \& Medicinal Chemistry, vol. 19, no. 18, pp. 5507-5519, 2011.

[6] A. Goeminne, M. Berg, M. McNaughton et al., " $N$-arylmethyl substituted iminoribitol derivatives as inhibitors of a purine specific nucleoside hydrolase," Bioorganic \& Medicinal Chemistry, vol. 16, no. 14, pp. 6752-6763, 2008.

[7] A. Goeminne, M. McNaughton, G. Bal et al., "Synthesis and biochemical evaluation of guanidino-alkyl-ribitol derivatives as nucleoside hydrolase inhibitors," European Journal of Medicinal Chemistry, vol. 43, no. 2, pp. 315-326, 2008.

[8] B. A. Horenstein, R. F. Zabinski, and V. L. Schramm, "A new class of C-nucleoside analogues. 1-(S)-aryl-1,4-dideoxy1,4-imino-D-ribitols, transition state analogue inhibitors of nucleoside hydrolase," Tetrahedron Letters, vol. 34, no. 45, pp. 7213-7216, 1993.

[9] C. Murruzzu and A. Riera, "Enantioselective synthesis of hydroxylated pyrrolidines via Sharpless epoxidation and olefin metathesis," Tetrahedron Asymmetry, vol. 18, no. 1, pp. 149-154, 2007.

[10] F. A. Davis, T. Ramachandar, J. Chai, and E. Skucas, "Asymmetric synthesis of $\alpha$-amino aldehydes from sulfinimine ( $N$-sulfinyl imine)-derived $\alpha$-amino 1,3-dithianes. Formal synthesis of (-)2,3-trans-3,4-cis-dihydroxyproline," Tetrahedron Letters, vol. 47, no. 16, pp. 2743-2746, 2006.

[11] T. S. Cooper, A. S. Larigo, P. Laurent, C. J. Moody, and A. $\mathrm{K}$. Takle, "O-(1-phenylbutyl)benzyloxyacetaldoxime, a versatile reagent for the asymmetric synthesis of protected 1,2aminoalcohols and 2-hydroxymethyl nitrogen heterocycles," Synlett, no. 10, pp. 1730-1732, 2002.

[12] R. Kumareswaran and A. Hassner, "Asymmetric synthesis of 1,4-dideoxy-1,4-imino-D-ribitol via stereoselective addition of allylphenylsulfone to an aryl $\mathrm{N}$-sulfinylimine," Tetrahedron Asymmetry, vol. 12, no. 24, pp. 3409-3415, 2002.

[13] D. M. Goli, B. V. Cheesman, M. E. Hassan, R. Lodaya, and J. T. Slama, "Synthesis of $(2 R, 3 R, 4 S)$-2-hydroxymethylpyrrolidine3,4-diol from (2S)-3,4-dehydroproline derivatives," Carbohydrate Research, vol. 259, no. 2, pp. 219-241, 1994.

[14] G. W. J. Fleet and J. C. Son, "Polyhydroxylated pyrrolidines from sugar lactomes: synthesis of 1,4-dideoxy-1,4-imino-d-glucitol from $\mathrm{D}$-galactonolactone and syntheses of 1,4-dideoxy1,4-imino-D-allitol, 1,4-dideoxy-1,4-imino-D-ribitol, and $(2 S, 3 R, 4 S)$-3,4-dihydroxyproline from d-gulonolactone," Tetrahedron, vol. 44, no. 9, pp. 2637-2647, 1988. 
[15] G. W. J. Fleet, J. C. Son, D. S. C. Green, I. C. di Bello, and B. Winchester, "Synthesis from D-mannose of 1,4-dideoxy1,4-imino-L-ribitol and of the $\alpha$-mannosidase inhibitor 1,4dideoxy-1,4-imino-D-talitol," Tetrahedron, vol. 44, no. 9, pp. 2649-2655, 1988.

[16] H. Setoi, H. Kayakiri, H. Takeno, and M. Hashimoto, "Synthesis of some polyhydroxylated pyrrolidine derivatives," Chemical and Pharmaceutical Bulletin, vol. 35, no. 10, pp. 3995-3999, 1987.

[17] T. B. Mercer, S. F. Jenkinson, B. Bartholomew et al., "Looking glass inhibitors: both enantiomeric $N$-benzyl derivatives of 1,4-dideoxy-1,4-imino-D-lyxitol [a potent competitive inhibitor of $\alpha$-D-galactosidase] and of 1,4-dideoxy-1,4-imino-L-lyxitol [a weak competitive inhibitor of $\alpha$-D-galactosidase] inhibit naringinase, an $\alpha$-L-rhamnosidase competitively," Tetrahedron Asymmetry, vol. 20, no. 20, pp. 2368-2373, 2009.

[18] H. Batra, R. M. Moriarty, R. Penmasta et al., "A concise, efficient and production-scale synthesis of a protected L-lyxonolactone derivative: an important aldonolactone core," Organic Process Research \& Development, vol. 10, no. 3, pp. 484-486, 2006.

[19] J. D. Williams, V. P. Kamath, P. E. Morris, and L. B. Townsend, "D-ribonolactone and 2,3-isopropylidene-(D-ribonolactone)," Organic Syntheses, vol. 82, pp. 75-79, 2005.

[20] H. Suh and C. S. Wilcox, "Chemistry of $\mathrm{F}_{1} \mathrm{~F}_{0}$-ATPase inhibitors. Stereoselective total syntheses of (+)-citreoviral and (-)citreoviridin," Journal of the American Chemical Society, vol. 110, no. 2, pp. 470-481, 1988.

[21] H. Kold, I. Lundt, and C. Pedersen, "Synthesis of L-ribono- and L-lyxino-lactone," Acta Chemica Scandinavica, vol. 48, no. 8, pp. 675-678, 1994.

[22] J. E. Baldwin, "Rules for ring closure," Journal of the Chemical Society, Chemical Communications, no. 18, pp. 734-736, 1976.

[23] E. C. Bigham, C. E. Gragg, W. R. Hall et al., "Inhibition of arabinose 5-phosphate isomerase. An approach to the inhibition of bacterial lipopolysaccharide biosynthesis," Journal of Medicinal Chemistry, vol. 27, no. 6, pp. 717-726, 1984.

[24] K. Jayakanthan, B. D. Johnston, and B. M. Pinto, "Stereoselective synthesis of 4/-selenonucleosides using the Pummerer glycosylation reaction," Carbohydrate Research, vol. 343, no. 10-11, pp. 1790-1800, 2008.

[25] K. Clinch, G. B. Evans, G. W. J. Fleet et al., "Syntheses and bio-activities of the L-enantiomers of two potent transition state analogue inhibitors of purine nucleoside phosphorylases," Organic \& Biomolecular Chemistry, vol. 4, no. 6, pp. 1131-1139, 2006. 

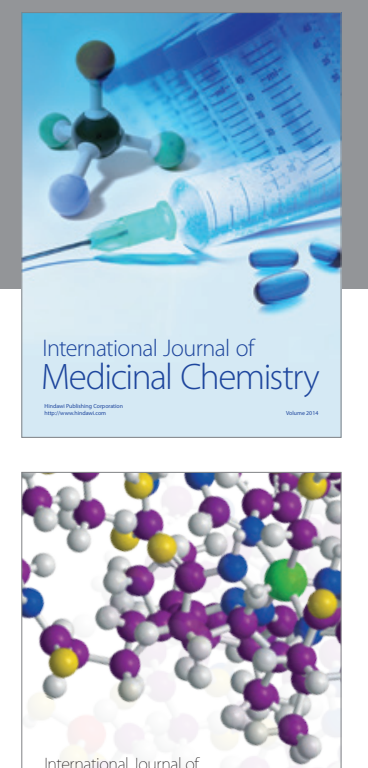

\section{Carbohydrate} Chemistry

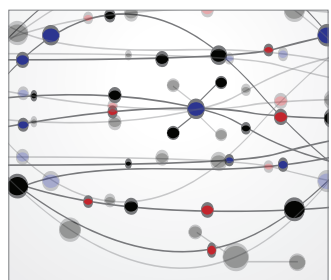

The Scientific World Journal
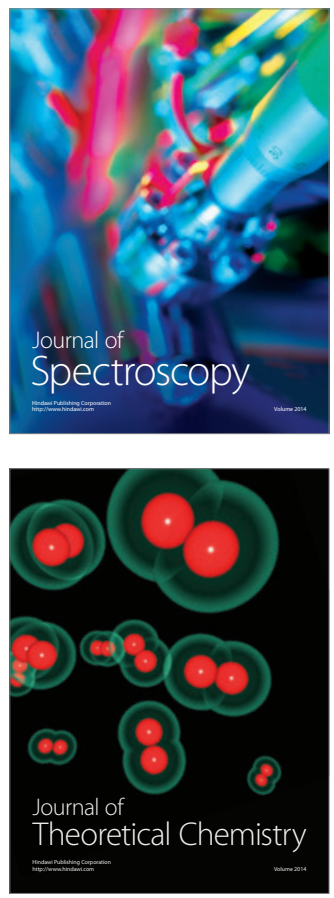
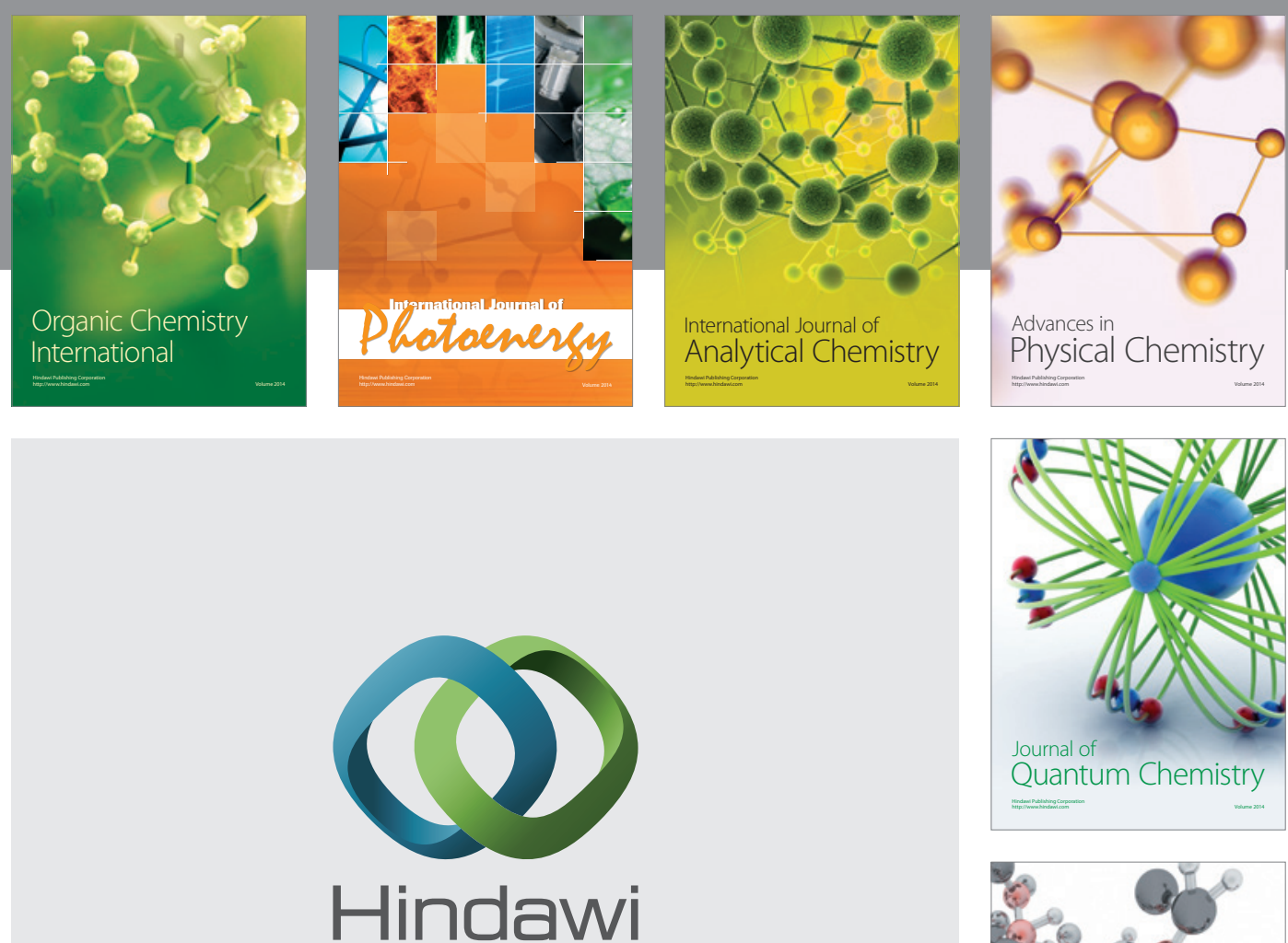

Submit your manuscripts at

http://www.hindawi.com

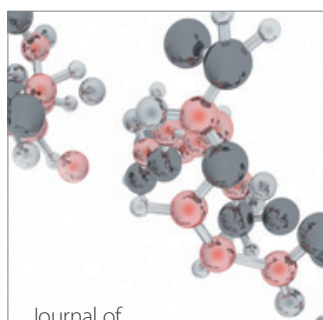

Analytical Methods

in Chemistry

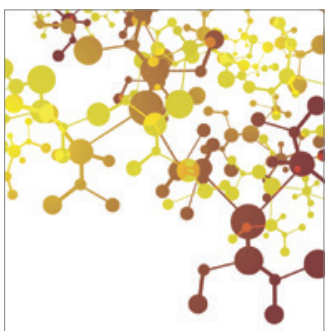

Journal of

Applied Chemistry

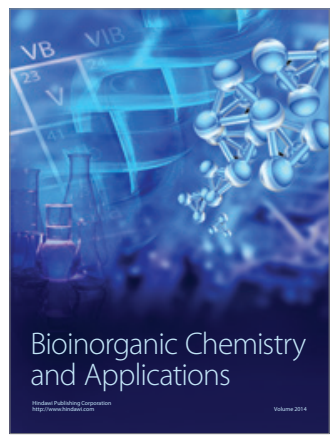

Inorganic Chemistry
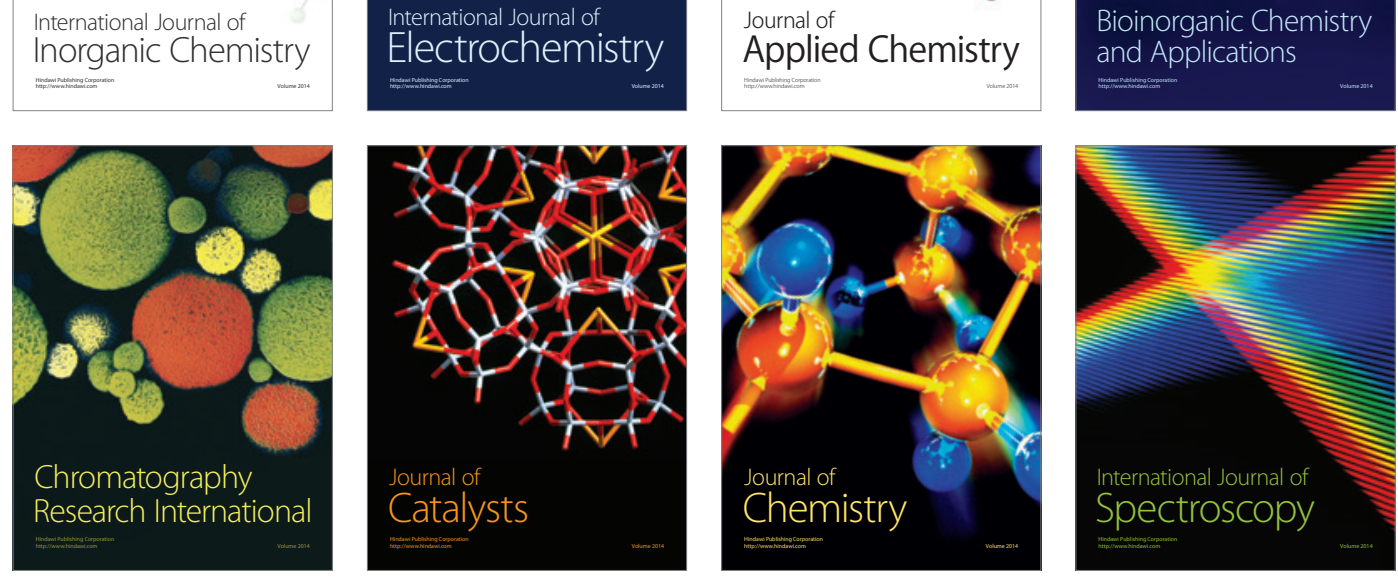